\title{
HIV Care in Times of COVID-19 - Rapid Treatment Start Seems as Vital and Cost-Effective Approach in Central and Eastern Europe
}

Justyna D. KOWALSKA ( $\nabla$ jdkowalska@gmail.com )

Medical University of Warsaw

Grzegorz WOJCIK

HTA Consulting

Jakub RUTKOWSKI

HTA Consulting

Ewa SIEWASZEWICZ

Gilead Sciences

\section{Research Article}

Keywords: HIV, rapid treatment, antiretroviral therapy, transmission risk, Eastern Europe, COVID-19

Posted Date: August 26th, 2021

DOl: https://doi.org/10.21203/rs.3.rs-812392/v1

License: (c) (i) This work is licensed under a Creative Commons Attribution 4.0 International License. Read Full License 


\section{Abstract}

Background:

In times of SARS-CoV-2 epidemic it is essential to deliver specialist HIV care with a maximum effectiveness, but minimum epidemiological risk. Therefore, we aimed to determine whether rapid linkage tocare definedas starting combined antiretroviral therapy (CART) at the day of first visit in HIV clinic is a cost-effective approach.

Methods:

The analysis used Markov's lifetime model presented in our previous study. The input data used in the model were updated in terms of costs, life expectancy tables and patient's characteristics. This analysis used information from the previous model about the additional cost of treatment and QALY lost in the life horizon for people newly infected with HIV. Number of new infected persons was estimated on the basis of available data.

Results:

Input data were available for 344 MSM patients who registered in HIV specialist care between 2016 and 2017. Estimated QALY loss due to no rapid treatmentin case of no taking (taking) into account viral load equal $0.018(0.022), 0.039(0.047), 0.131(0.158)$ respectively in low, medium and high-risk transmission groups. RapidcART initiation was dominant regardless of the chosenscenarios.

Conclusions:

Taking into account HIV transmission in cost-effectiveness analysis indicates that rapid-initiation of HIV treatment is profitable.

\section{Background}

The sustainability of already achiever progress in stopping HIV, defined by 90-90-90 WHO goal, may be endangered in times of SARS-CoV-2 epidemic. ${ }^{1}$ In addition the responsibilities of clinical centres expanded as it is essential to deliver specialist HIV care with maximum effectiveness, but minimum epidemiological risk. Although HIV infection itself is not considered as higher risk of SARS-CoV-2 infection or more severe COVID-19, people living with HIV have many co-morbiditiesthat pose such risk. $^{2,3}$ In addition it cannot be exclude that HIV-positive people who are not yet on treatment and those with low CD4+ count may be at increased risk of COVID-19. ${ }^{2}$ Therefore patients would additionally benefit from limiting number of contacts with other patients and healthcare providers. Rapid treatment start presents such advantage through limiting number of visits and contacts. In addition rapid stars proved to be effective method of linkage to care and is recommended by the IAS-USA, in recognition of many structural barriers that may prevent people to be immediately linked to care. ${ }^{4}$ 
HIV care in times of SARS-CoV-2 pandemic faced new challenges and needs. European region was disproportionately affected by the epidemic. In Central and Eastern Europe half of physicians involved in HIV care was at the same time involved in COVID-19 treatment. ${ }^{5}$ Therefore rapid treatment start, defined as starting therapy on the first clinical visit and prior to obtaining test resultsseems as vital option. Here we aimed to determine whether starting combined antiretroviral therapy (rapid cART) at the first visit in HIV clinic is a cost-effective approach for this region of Europe.

\section{Methods}

Our analyses were performed to assess the potential benefits and costs in the population of men having sex with men(MSM) related to immediate starting treatment at the time of HIV diagnosis compared to standard treatment path.

For this paper a new simple computational model was built to assess the cost-effectiveness of rapid CART treatment for newly diagnosedHIV infected patients, from the public payer's perspective. Due to the analyzed disease and compared treatment paths, it were decided to take into account the effects and costs only in the period from diagnosis to start cART (possible gains resulting from earlier treatment at later time were omitted). Because of characteristics of HIV treatment and short period of delaying treatment, the presented simplification should not cause significant differences in patient's state of health and precisely illustrates the incremental effect of compared paths of treatment (Figure 1). The above assumption in case of previously published papers suggesting that delaying to cART is associated with additional costs, could be considered as a conservative approach. ${ }^{6}$

In our calculations, we also used the lifetime Markov model built during previous study (Kowalska 2017), which allowed to perform cost-utility analysis and determinate quality-adjusted lost years of life and additional costs for the payer for newly HIV infected patients. ${ }^{6}$

The model has one-month cycles and takes into account 33 events or illnesses divided into 18 health states and 8 additional events or diseases affecting estimated costs and the length of life. The baseline state of the model is an asymptomatic HIV, that was the people with HIV who did not experience additional comorbidities. In each cycle of analysis, patients were distributed between health states with assigned corresponding probabilities. We made the assumption, that after changing baseline health state it was not possible for the person to change their health state, except for death incidence, there was no possibility of the occurrence of the same event repeatedly and no possibility of having several diseases at the same time(Figure 2).Detailed information about used Markov model was described in the previous study Kowalska $2017 .^{6}$

For the purposes of this analysis, the previously developed Markov model were also updated in case of baseline characteristics of patientswho registered in HIV specialist care between 1st January 2016 and 31st December 2017: mean CD4+ cells count, median HIV RNA and others (Table 1) and costs.

\section{Risk of HIV transmission per sexual act}


In the first stage, based on the unsystematic literature review, the number of potentially avoided new HIV infections were estimated due to rapid treatment implementation.

To find the necessary data on the risk of HIV transmission due to a sexual acts among MSMs, a research of the Medline medical database (via Pubmed) were performed. During the search, attempts were made to narrow down to the most reliable studies, i.e. meta-analysis that would be best suitable to our analysis population namely MSM patients not yet treated with cART. As part of the search, three publications were finally included to the analysis, Lasry 2014, ${ }^{7}$ Patel $2014^{8}$ and Baggaley $2018^{9}$ in which the risk of transmission per sexual act were found(Table 2).Due to the fact that the Baggaley 2018 study was published quite recently in 2018 and its significant extent of scope of study is also included in other reviews, it was decided to use this data in the base case scenario of analysis.In addition, the results from the remaining reviews were decided to be tested in a sensitivity analysis.

\section{Time from diagnosis to start CART treatment}

Based on the data collected for the MSM who registered in HIV specialist care, such as time of conducting the HIV-test, time of HIV diagnosis and the start of cART treatment, the average and median time of delay in access to therapy were determined. The statistical analysis of survival curves for the time to start treatment. was conducted. In the final calculations, curves based on the generalized gamma distribution (main scenario) and Weibull distribution (sensitivity analysis) were selected cause by the best fit according to the AIC and BIC criteria (Figure 3).

\section{Viral load and risk transmission}

Literature studies clearly show that plasma viral load is directly associated with risk of sexual transmission of HIV. Hence, the new simple computational model built for this analysis allows to perform calculations for two different variants: 1. Excluding impact of viral load at the risk of HIV transmission and 2. Including the level of viremia.

The baseline risk of HIV transmission adopted based on the data found in the reviewwas adjusted for HIV RNA viral load according to the Quinn $2000^{10}$ study. In that paper, it was estimated thar each log increase in viral load was associated with an increase by a factor of 2.45 in the risk of transmission.

In the first stage, the data for the cohort was stratified into five risk groups depending on the viral load levels, similarly to the Quinn $2000^{10}$ publication. Based on this data, the average level of HIV RNA viral load in each of the five groups was also determined.Finally, due to the small size of the group with level of viral load between 1.70 to $3.54 \log _{10}$ HIV RNA copies/ml (only 11 patients from 344 patients from the cohort, $3 \%$ ) it was decided to include them into group of patients under $3.54 \log _{10}$ copies HIV RNA copies. Then, the probability of HIV transmission was determined for each group based on the difference between mean viral load in each group compared to the mean value on level of HIV viral load in the whole cohort and using data from the Quinn 2000 study. 
For example, in the group of patients with 1.70-3.54 $\log _{10} \mathrm{HIV}$ RNA copies $/ \mathrm{ml}$, the average level of viremia was $2.77 \log _{10}$ copies and was about $1.86 \log _{10}$ copies $/ \mathrm{ml}$ lower than the average level of viral load in the entire cohort. According to the data in the Quinn study, this difference is associated with more than 5-fold reduction risk of sexual transmission to $19 \%$ of the baseline risk from Baggaley $2018^{9}$ and others.

Ultimately, when impact of viral load at the risk of HIV transmission was included into our assesment, the propability of HIV transmission per insertive sexual act for patients with less than $3.54 \log _{10}$ HIV RNA copies $/ \mathrm{ml}$ was established at level $0 \cdot 01 \%$ compared to $0 \cdot 17 \%$ reported in the Baggaley $2018^{9}$ study. Detailed information about probabilites of new HIV infections per sexual act for all stratifield groups was preseneted in Table 2.

\section{Risk profiles of sexual behavior}

In our analysis, HIV transmission was assumed to occur only through sexual contacts.

The probability of infection was based on data found in published meta-analyzes. Our calculation also takes into account the impact of condom uses for final risk of transmission.

Due to the methodology of the analysis and showing the incremental effect of immediate starting treatment at the time of HIV diagnosis, the estimated number of new HIV infections relates to the period in whichpatient is not receiving cART. Profiles of the risk of transmission were adopted in a similar way as in the previous study Kowalska $2017^{6}$ i.e based on the average number of sexual partners, number of sexual acts, \% frequency of condom use per act.

Additionally, we assumed that each patient from the analysed cohort had the same number of intercourses and had the same number of intercourses with each sexual partner. For the medium risk scenario, which was considered a baseline model, the rate of transmission was estimated assuming that an average HIV positive person has 10 partners per year, 10 monthly sex acts and $50 \%$ frequency of condom use per act. For the low and high-risk scenarios we assumed a person to have 3 and 50 partners per year, 10 and 20 sex acts per month and $90 \%$ and $0 \%$ coverage with condom use, respectively.

In our analysis also assumed that $28 \%$ of MSM patients have HIV+ partners (this assumption reduces the total number of new potential infections) ${ }^{6}$

\section{Costs and other data}

For the purposes of this analysis, previously Markov model was updated in terms of each health state representing different AIDS and Non-AIDS defining illness and the costs of cART treatment. The costs of CART treatment were adopted based on actual data from the National Program of cART Treatment and expert opinion, which was adopted at EUR 482 per month (461EUR drugs and 22 EUR monitoring treatment)while the cost of treating health states were adjusted based on inflation rate between 2015 and 
2019 published by the Central Statistical Office. ${ }^{11}$ Additionally, data about patient mortality used in Markov model, i.e. life expectancy tables was updated.

Additional costs related to the implementation of rapid cART were not included due to the method of financing of Centers of HIV Treatment in Poland as flat-fee. The simplification approach should not have a significant impact on inference from the analysis and results.

\section{Results}

\section{Transmission risk with no adjustment for viral load level}

In base case scenario (scenario A1), which include data from Baggaley 2018, the estimated avoided sexual HIV transmission rate within rapid CART therapy was from 0.011 to 0.076 compared to receiving CART immediately later. A lower transmission rate due rapid CART leads to additional QALY gained and savings costs of treatment associated with avoiding new infections. Estimated additional QALY gained due to avoid new HIV infections was from 0.018 to 0.131 depends on risk profile (low, medium and high). The additional costs savings of treatment associated with lack of new infections range fromEUR745 for low risk profile to EUR 5351 for high-risk profile.

Despite the additional costs of treatment since day of HIV diagnosis related to the implementation of rapid CART, this path were associated with savings for the public payer in the amount from EUR331 to EUR4 937 in lifetime horizon per 1 included patients.

Rapid cART therapy was found to be dominant (more effective and cost-savings) than standard path treatment regardless of the risk profile (Table 3 ).

\section{Transmission risk adjusted for viral load level}

Next, we carried out the analysis with the risk of MSM sexual HIV transmission adjusted for level of HIV RNA viral load (scenario A2). In this case scenario (data from Baggaley 2018 was used), the estimated avoided sexual HIV transmission rate within rapid cART therapy was from 0.013 to 0.092 compared to receiving cART immediately later. A lower transmission rate due rapid CART leads to additional QALY gained and savings costs of treatment associated with avoiding new infections. Estimated additional QALY gained due to avoid new HIV infections was from 0.022 to 0.158 depends on risk profile (low, medium and high). The additional costs savings of treatment associated with lack of new infections range from EUR896 for low risk profile to EUR 6454 for high-risk profile.

Despite the additional costs of CART since day of HIV diagnosis related to the implementation of rapid CART, this path were associated with savings for the public payer in the amount from EUR 482 to EUR 6 041 in lifetime horizon per 1 included patients. If transmission risk was adjusted for viral load, estimated savings for national payer is even higher than in scenario when viral load was not included. 
Rapid cART therapy was found to be dominant (more effective and cost-savings) than standard path treatment regardless of the risk profile (Table 3).

\section{Patients with low level of viral load (1.70 - 3.54 $\log _{10}$ copies/ml)}

In addition, as part of the work of this analysis, calculations for group of patients with low level of viral load (50-3499 copies) were conducted (scenario A3). The estimated avoided sexual HIV transmission rate within rapid cART therapy was from 0.002 to 0.014 compared to receiving cART immediately later. A lower transmission rate due rapid CART leads to additional QALY gained and savings costs of treatment associated with avoiding new infections. Estimated additional QALY gained due to avoid new HIV infections was from 0.003 to 0.025 depends on risk profile (low, medium and high). The additional costs savings of treatment associated with lack of new infections range from EUR 141 for low risk profile to EUR 1011 for high-risk profile.

The calculated total treatment costs of implementation of rapid cARTfor public payer were EUR272 and EUR 110 for low and medium risk profiles, respectively. This means that for a group of patients with both low viral load and low risk profile, rapid cART is not a cost-effective treatment path (ICER $=78490$ EUR).In case of medium risk profile, rapid cART is cost-effective treatment path (ICER $=14853$ EUR), but not costsaving like for high risk profile of patients (597 EUR savings for public payer per 1 included patient) (Table 3).

Sensitivity analyses

To test, whether the model is solid and the inference is sensitive we have run the calculation with three additional scenarios of the data source (Patel 2014 and Lasry 2014 for scenario S1 and scenario S2respectively) and used Weibull distribution (scenario S3). Regardless of the analyzed scenario, the obtained results was similar to results presented in the base case scenario. When data for risk of HIV transmission from the Patel 2014 or Lasry 2014was used and a curve of time from diagnosis to start CART was fitted to the Weibull distribution, rapid therapy was also found to be dominant (more effective and cost-savings) than standard path treatment. The estimated savings for the public payer were associated with the amount from EUR 341 to EUR 5009 and EUR 609 to EUR 6 943in lifetime horizon per 1 included patient for Patel 2014 and Lasry 2014 data, respectively. If additionally, the calculations were taken into account the effect of viral load (scenario S3), then the savings for the public payer ranged from EUR 452 to EUR 5820(Table 3

\section{Discussion}

Rapid cART is a concept of starting treatment as soon as it is possible, prefferentially at the day of diagnosis, even when most of laboratory tests results are not available ${ }^{12}$. This approach is based on three main achievements of modern cATR: developing antiretroviral medicine with minimal toxicity, proving their effectiveness irrespective of CD4 count or HIV viral load and confirming that viral suppression protects HIV-negative sexual partners from acquiring. ${ }^{13-16}$ The most important effect of 
rapid CART is improved treatment up-take and grater viral suppression, as well as improved retention in care. ${ }^{17,18}$ However this was well proven only for low and middle income countries, wherase adequate studies in a high income countries with more complex healthcare systems are lacking. ${ }^{17}$ This is in particular relevant for Central and Eastern Europe, where most countries have more developed healthcare systems and are considered to be high income country. At the same time linkage to care in this region remians unsatisfactory and an important obstacle in adapting WHO strategy, namely providing cART to $90 \%$ of those with diagnosed HIV infection. ${ }^{19-22} \mathrm{WHO}$ has already recommended rapid cART start strategy in 2017. ${ }^{23}$ Governments and scientific societies in Europe seem to be more reluctant in adapting bold strategies due to lack of proper evidence based on local population. ${ }^{24}$

Here we present that implementation of rapid cART on a national scale generates health benefits and reduces the number of HIV infections and is associated with additional savings for the payer in the lifetime horizon. In addition, falling prices of cART drugs related to expiration of patent protection for some drugs causes that the initial cost of implementation such a solution is increasingly lower. This should facilitate decision-making by the public payer.

In the case of subgroups analysis, for most of them the introduction of rapid cART is at least costeffective or even a dominant intervention (cheaper and more effective). Only in the population of people with HIV viral load and low risk of sexual behavior, rapid cART may not be a cost-effective intervention frompublic payer's point of view.

Thereis a numberoflimitationswhichneedtobeconsideredwhileinterpretingourdata. Firstly the results obtained in a group of patients with very low viral load and a low risk of sexual behavior, rapid cART probably may not be cost-effective path. However, considering the data about characteristics of HIV patients, the percentage of such patients is very low and should not affect the results of the analysis.Moreover rapid CART seems to be especially beneficial to those at higherst risk of acquiering HIV trough sexual contacts, which due to changing trends in epidemic in Central and Eastern European region seems to be a key factor for HIV prevention. ${ }^{25}$

It should be noted, that taking into account the impact of HIV viral load on final transmission risk was not the primary aim of this study. Hence, our assumptions and calculations in this area are characterized some uncertainty and limitations, which is an additional area for exploration in the future. Regardless of whether rapid CART is a profitable intervention in population with the lowest risk of HIVtransmission, it should be noted that people with low HIV viremia at diagnosis accounts for less than $5 \%-8 \%$ of those diagnosed with HIV and at least half of newly diagnosed people are presenting high risk behaviours. ${ }^{26}$

The analysis included only the costs of additional cART treatment and the total costs of treating newly infected person. We did not include the other costs associated with adapting HIV treatment centers to implementation a new path of treatment or additional workload of medical staff due to the characteristics of the healthcare system in Poland. In Polish settings, other non-drug related costs in HIV treatment centers in Poland are financed on a flat-rate and it should not significantly affect the results of the analysis. 
In summary, rapid cART represents a cost-effective strategy for Poland, which could be also relevant for other countries from Central and Eastern European region. In addition in the time of current COVID-19 pandemic it provides a safer option, reducing the number of necessary personal visits in the clinic and improving linkage to care.

\section{Abbreviations}

AIDS -Acquired Immune Deficiency Syndrome

AIC - Akaike information criterion

BIC - Bayesian information criterion

cART - combined antiretroviral therapy

CD4 - Claster differentiation 4

COVID-19 - Coronavirus 19 Disease

EUR - euro

HIV - Human Immunodeficiency Virus

HIV RNA - HIV ribonucleic acid

IAS-USA - International Antiviral Society - USA

IQR -interquartile range

MSM - men having sec with men

QALY- quality-adjusted life year

SARS-CoV-2 - severe acute respiratory syndrome coronavirus 2

\section{Declarations}

\section{Ethics}

This study was performed in accordance with the Declaration of Helsinki, as well as all the relevant local guidelines and regulations. The ethical approval was obtained from the Bioethical Committee of the Medical University of Warsaw (Komisja Bioetyczne Warszawksiego Uniwersytetu Medycznego) and a waiver for informed consent was granted. Information and documentation to support this statement is made available to the Editor on request. All data used in the study were fully anonymized before any of the authors had accessed them.

Availability of data and materials: The datasets used and/or analyzed during the current study are available from the corresponding author on reasonable request.

\section{Consent for publication}

All authors consent for publishing this work.

\section{Acknowledgements}

Competing interests:All authors certify that they have no affiliations with or involvement in any organization or entity with any financial interest (such as honoraria; educational grants; participation in 
speakers' bureaus; membership, employment, consultancies, stock ownership, or other equity interest; and expert testimony or patent-licensing arrangements), or non-financial interest (such as personal or professional relationships, affiliations, knowledge or beliefs) in the subject matter or materials discussed in this manuscript.

Funding: The study was supported by Gilead Sciences Poland by covering the cost of work performed by HTA commercial company. The funder did not have any influence on the study design, data collection and analysis, preparation of the manuscript or decision to publish. The specific roles of all authors are articulated in the 'author contributions' section. JR and GW are hired by HTA company. ES is hired by the Gilead Sciences Poland company. JDK is not hired by any of this commercial institutions and did not receive financial support or author's salary in relation to this work. The funder do not alter adherence to journal's policies on sharing data and supplementary materials.

\section{Authors' contributions:}

JDK, GW, JR, ES - Conceptualization (equally),

JDK, GW, JR - Data curation

GW, JR - Formal analysis

ES - Funding acquisition

JDK, GW, JR - Investigation

JDK, GW, JR, ES - Methodology

JDK, ES - Supervision

GW, JR - Validation

JDK, GW, JR - Visualization

JDK, GW, JR - Writing - original draft

JDK - Writing - review and editing

All authors read and approved the final manuscript.

\section{References}

1. Jiang H, Zhou Y, Tang W. Maintaining HIV care during the COVID-19 pandemic. Lancet HIV. 2020;7(5):e308-9.

2. BHIVA, DAIG, EACS, GESIDA \& Polish Scientific AIDS Society Statement on risk of COVID-19 for people living with HIV (PLWH) - EACSociety [Internet]. [cited 1 October 2020]. Available at: 
https://www.eacsociety.org/home/bhiva-daig-eacs-gesida-and-polish-scientific-aids-societystatement-on-risk-of-covid-19-for-people-living-with-hiv-plwh.html

3. Härter G, Spinner CD, Roider J, Bickel M, Krznaric I, Grunwald S, et al. COVID-19 in people living with human immunodeficiency virus: a case series of 33 patients. Infection. October 2020;48(5):681-6.

4. Saag MS, Benson CA, Gandhi RT, Hoy JF, Landovitz RJ, Mugavero MJ, et al. Antiretroviral Drugs for Treatment and Prevention of HIV Infection in Adults: 2018 Recommendations of the International Antiviral Society-USA Panel. JAMA. 24 2018;320(4):379-96.

5. Kowalska JD, Skrzat-Klapaczyńska A, Bursa D, Balayan T, Begovac J, Chkhartishvili N, et al. HIV care in times of the COVID-19 crisis - Where are we now in Central and Eastern Europe? Int J Infect Dis IJID Off Publ Int Soc Infect Dis. July 2020;96:311-4.

6. Kowalska JD, Wójcik G, Rutkowski J, Ankiersztejn-Bartczak M, Siewaszewicz E. Modelling the costeffectiveness of HIV care shows a clear benefit when transmission risk is considered in the calculations - A message for Central and Eastern Europe. Law M, redaktor. PLOS ONE. 13 November 2017;12(11):e0186131.

7. Lasry A, Sansom SL, Wolitski RJ, Green TA, Borkowf CB, Patel P, et al. HIV sexual transmission risk among serodiscordant couples: assessing the effects of combining prevention strategies. AIDS. June 2014;28(10):1521-9.

8. Patel P, Borkowf CB, Brooks JT, Lasry A, Lansky A, Mermin J. Estimating per-act HIV transmission risk: a systematic review. AIDS. June 2014;28(10):1509-19.

9. Baggaley RF, Owen BN, Silhol R, Elmes J, Anton P, McGowan I, et al. Does per-act HIV-1 transmission risk through anal sex vary by gender? An updated systematic review and meta-analysis. Am J Reprod Immunol. listopad 2018;80(5):e13039.

10. Quinn TC, Wawer MJ, Sewankambo N, Serwadda D, Li C, Wabwire-Mangen F, et al. Viral Load and Heterosexual Transmission of Human Immunodeficiency Virus Type 1. N Engl J Med. 30 March 2000;342(13):921-9.

11. Główny Urząd Statystyczny / Obszary tematyczne / Ceny. Handel / Wskaźniki cen / Wskaźniki cen towarów i usług konsumpcyjnych (pot. inflacja) / Roczne wskaźniki cen towarów i usług konsumpcyjnych od 1950 roku [Internet]. [cited 29 September 2020]. Availableat: https://stat.gov.pl/obszary-tematyczne/ceny-handel/wskazniki-cen/wskazniki-cen-towarow-i-uslugkonsumpcyjnych-pot-inflacja-/roczne-wskazniki-cen-towarow-i-uslug-konsumpcyjnych/

12. Boyd MA, Boffito M, Castagna A, Estrada V. Rapid initiation of antiretroviral therapy at HIV diagnosis: definition, process, knowledge gaps. HIV Med. 2019;20 Suppl 1:3-11.

13. Cohen MS, Chen YQ, McCauley M, Gamble T, Hosseinipour MC, Kumarasamy N, et al. Prevention of HIV-1 infection with early antiretroviral therapy. N Engl J Med. 11 August 2011;365(6):493-505.

14. Kowalska JD, Reekie J, Mocroft A, Reiss P, Ledergerber B, Gatell J, et al. Long-term exposure to combination antiretroviral therapy and risk of death from specific causes: no evidence for any previously unidentified increased risk due to antiretroviral therapy. AIDS Lond Engl. 28 January 2012;26(3):315-23. 
15. Prognosis of patients treated with cART from 36 months after initiation, according to current and previous CD4 cell count and plasma HIV-1 RNA measurements: AIDS. October 2009;23(16):2199208.

16. Brown A, Gill O, Delpech V. HIV treatment as prevention among men who have sex with men in the UK: is transmission controlled by universal access to HIV treatment and care?: HIV treatment as prevention in MSM in UK. HIV Med. October 2013;14(9):563-70.

17. Mateo-Urdiales A, Johnson S, Smith R, Nachega JB, Eshun-Wilson I. Rapid initiation of antiretroviral therapy for people living with HIV. Cochrane Infectious Diseases Group, ed. Cochrane Database Syst Rev [Internet]. 17 July 2019 [cited 29 September 2020]; Availableat: http://doi.wiley.com/10.1002/14651858.CD012962.pub2

18. Lilian RR, Rees K, Mclntyre JA, Struthers HE, Peters RPH. Same-day antiretroviral therapy initiation for HIV-infected adults in South Africa: Analysis of routine data. Yotebieng M, redaktor. PLOS ONE. 14 January 2020;15(1):e0227572.

19. Ankiersztejn-Bartczak M, Firląg-Burkacka E, Czeszko-Paprocka H, Kubicka J, Cybula A, Horban A, et al. Factors responsible for incomplete linkage to care after HIV diagnosis: preliminary results from the Test and Keep in Care (TAK) project: Incomplete linkage to care: TAK results. HIV Med. February 2015;16(2):88-94.

20. Gokengin D, Oprea C, Begovac J, Horban A, Zeka AN, Sedlacek D, i in. HIV care in Central and Eastern Europe: How close are we to the target? Int J Infect Dis. May 2018;70:121-30.

21. Kowalska JD, Shepherd L, Ankiersztejn-Bartczak M, Cybula A, Czeszko-Paprocka H, Firląg-Burkacka E, et al. Poor Linkage to Care Despite Significant Improvement in Access to Early cART in Central Poland - Data from Test and Keep in Care (TAK) Project. Paraskevis D, redaktor. PLOS ONE. 6 October 2016;11(10):e0162739.

22. Pokrovskaya A, Popova A, Ladnaya N, Yurin O. The cascade of HIV care in Russia, 2011-2013. J Int AIDS Soc. November 2014;17:19506.

23. WHO. Recommendation for rapid initiation of ART - Guidelines for Managing Advanced HIV Disease and Rapid Initiation of Antiretroviral Therapy - NCBI Bookshelf [Internet]. [cited 29 September 2020]. Available at: https://www.ncbi.nlm.nih.gov/books/NBK475972/

24. Ryom L, Cotter A, De Miguel R, Béguelin C, Podlekareva D, Arribas J, i in. 2019 update of the European AIDS Clinical Society Guidelines for treatment of people living with HIV version 10.0. HIV Med [Internet]. 3 September 2020 [cited 29 September 2020]; Available at: https://onlinelibrary.wiley.com/doi/10.1111/hiv.12878

25. Bavinton BR, Pinto AN, Phanuphak N, Grinsztejn B, Prestage GP, Zablotska-Manos IB, etal. Viral suppression and HIV transmission in serodiscordant male couples: an international, prospective, observational, cohort study. Lancet HIV. August 2018;5(8):e438-47.

26. Laeyendecker O, Redd AD, Lutalo T, Gray RH, Wawer M, Ssempijja V, et al. Frequency of Long-Term Nonprogressors in HIV-1 Seroconverters From Rakai Uganda: JAIDS J Acquir Immune Defic Syndr. November 2009;52(3):316-9. 


\section{Tables}

Table 1. Baseline characteristic of newly registered patients in routine medical care 2016-2017

\begin{tabular}{|c|c|}
\hline Parameters & Value \\
\hline Mean CD4+ count [cells/mm3] (SD) & $391(209 \cdot 6)$ \\
\hline $\begin{array}{l}\text { Patients with } 1.70-3.54 \log _{10} \text { HIV RNA copies/ml } \\
(50-3499 \text { HIV RNA copies/ml) [n / \%] }\end{array}$ & $32(9 \cdot 3 \%)$ \\
\hline $\begin{array}{l}\text { Patients with 3.54- } 4 \cdot 00 \log _{10} \text { HIV RNA copies/ml } \\
\text { (3 } 500 \text { - } 9999 \text { HIV RNA copies/ml) [n / \%] }\end{array}$ & $33(9 \cdot 6 \%)$ \\
\hline $\begin{array}{l}\text { Patients with } 4.00-4.70 \log _{10} \text { HIV RNA copies/ml } \\
(10000-49999 \text { HIV RNA copies/ml) [n / \%] }\end{array}$ & $99(28 \cdot 8 \%)$ \\
\hline $\begin{array}{l}\text { Patients with }>4 \cdot 70 \log _{10} \text { HIV RNA copies/ml } \\
(50000+\text { HIV RNA copies/ml) [n / \%] }\end{array}$ & $180(52 \cdot 3 \%)$ \\
\hline Median HIV RNA [ $\log _{10}$ copies/ml ] (IQR) & $4 \cdot 72(4 \cdot 22-5 \cdot 24)$ \\
\hline Mean age [years] (SD) & $33(8 \cdot 24)$ \\
\hline Males pct. [\%] & $100 \%$ \\
\hline MSM pct. [\%] & $100 \%$ \\
\hline
\end{tabular}

Table 2. Risk of HIV transmission when viral load is included 


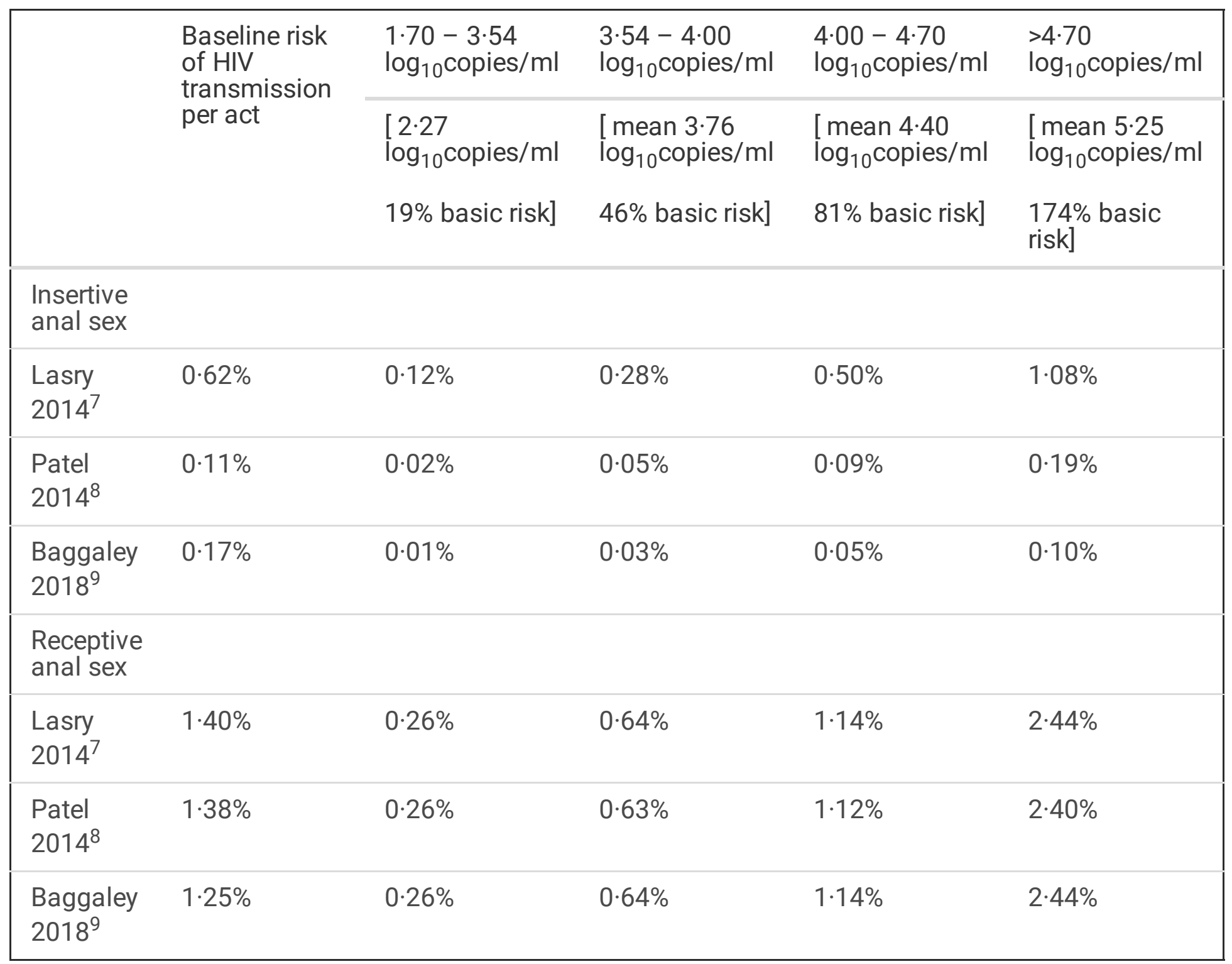

Table 3. Results of analysis 


\begin{tabular}{|c|c|c|c|c|c|c|}
\hline \multirow[b]{2}{*}{ Scenario } & \multicolumn{2}{|c|}{$\begin{array}{l}\text { Incremental results / base } \\
\text { case scenario }\end{array}$} & \multicolumn{4}{|c|}{ Incremental results / sensitive analysis } \\
\hline & A1 & A2 & A3 & S1 & S2 & S3 \\
\hline \multirow[t]{2}{*}{ Risk profile } & $\begin{array}{l}\text { Medium } \\
\text { risk }\end{array}$ & $\begin{array}{l}\text { Medium } \\
\text { risk }\end{array}$ & $\begin{array}{l}\text { Medium } \\
\text { risk }\end{array}$ & $\begin{array}{l}\text { Medium } \\
\text { risk }\end{array}$ & $\begin{array}{l}\text { Medium } \\
\text { risk }\end{array}$ & $\begin{array}{l}\text { Medium } \\
\text { risk }\end{array}$ \\
\hline & $\begin{array}{l}\text { (Low risk } \\
\text { / High } \\
\text { Risk) }\end{array}$ & $\begin{array}{l}\text { (Low risk } \\
\text { /High } \\
\text { Risk) }\end{array}$ & $\begin{array}{l}\text { (Low risk } \\
\text { / High } \\
\text { Risk) }\end{array}$ & $\begin{array}{l}\text { (Low risk } \\
\text { /High } \\
\text { Risk) }\end{array}$ & $\begin{array}{l}\text { (Low risk } \\
\text { / High } \\
\text { Risk) }\end{array}$ & $\begin{array}{l}\text { (Low risk } \\
\text { / High } \\
\text { Risk) }\end{array}$ \\
\hline \multirow{2}{*}{$\begin{array}{l}\text { Fixed cost of rapid } \\
\text { treatment [EUR] }\end{array}$} & 0 & 0 & 0 & 0 & 0 & 0 \\
\hline & $(0 / 0)$ & $(0 / 0)$ & $(0 / 0)$ & $(0 / 0)$ & $(0 / 0)$ & $(0 / 0)$ \\
\hline \multirow{2}{*}{$\begin{array}{l}\text { Cost of cART treatment } \\
\text { since day of diagnosis } \\
\text { [EUR] }\end{array}$} & 414 & 414 & 414 & 414 & 414 & 414 \\
\hline & $\begin{array}{l}(414 / \\
414)\end{array}$ & $\begin{array}{l}(414 / \\
414)\end{array}$ & $\begin{array}{l}(414 / \\
414)\end{array}$ & $\begin{array}{l}(414 / \\
414)\end{array}$ & $\begin{array}{l}(414 / \\
414)\end{array}$ & $\begin{array}{l}(414 / \\
414)\end{array}$ \\
\hline \multirow{2}{*}{$\begin{array}{l}\text { Cost of treatment new } \\
\text { infections [EUR] }\end{array}$} & -1601 & -1929 & -303 & -1623 & -2199 & -1863 \\
\hline & $\begin{array}{l}(-745 / \\
-5351)\end{array}$ & $\begin{array}{l}(-896 /-6 \\
454)\end{array}$ & $\begin{array}{l}(-141 /-1 \\
011)\end{array}$ & $\begin{array}{l}(-755 / \\
-5423)\end{array}$ & $\begin{array}{l}(-1022 / / \\
-7356)\end{array}$ & $\begin{array}{l}(-866 /-6 \\
234)\end{array}$ \\
\hline Total costs & -1188 & -1515 & 110 & -1209 & -1786 & -1450 \\
\hline [EUR] & $\begin{array}{l}(-331 /-4 \\
937)\end{array}$ & $\begin{array}{l}(-482 /-6 \\
041)\end{array}$ & $\begin{array}{l}(272 / \\
-597)\end{array}$ & $\begin{array}{l}(-341 /-5 \\
009)\end{array}$ & $\begin{array}{l}(-609 /-6 \\
943)\end{array}$ & $\begin{array}{l}(-452 /-5 \\
820)\end{array}$ \\
\hline \multirow{2}{*}{$\begin{array}{l}\text { Sexual HIV } \\
\text { transmission }\end{array}$} & $-0 \cdot 023$ & $-0 \cdot 028$ & $-0 \cdot 004$ & $-0 \cdot 023$ & $-0 \cdot 031$ & $-0 \cdot 027$ \\
\hline & $\begin{array}{l}(-0.011 / \\
-0.076)\end{array}$ & $\begin{array}{l}(-0.013 / \\
-0.092)\end{array}$ & $\begin{array}{l}(-0 \cdot 002 / \\
-0 \cdot 014)\end{array}$ & $\begin{array}{l}(-0.011 / \\
-0.077)\end{array}$ & $\begin{array}{l}(-0 \cdot 015 / \\
-0 \cdot 105)\end{array}$ & $\begin{array}{l}(-0.012 / \\
-0.089)\end{array}$ \\
\hline \multirow[t]{2}{*}{ LYG } & $0 \cdot 017$ & 0.020 & 0.003 & $0 \cdot 017$ & 0.023 & 0.020 \\
\hline & $\begin{array}{l}(0.008 / \\
0.056)\end{array}$ & $\begin{array}{l}(0.009 / / \\
0.068)\end{array}$ & $\begin{array}{l}(0.001 / / \\
0.011)\end{array}$ & $\begin{array}{l}(0.008 / \\
0.057)\end{array}$ & $\begin{array}{l}(0.011 / / \\
0.077)\end{array}$ & $\begin{array}{l}(0.009 / \\
0.065)\end{array}$ \\
\hline \multirow[t]{2}{*}{ QALY } & 0.039 & 0.047 & 0.007 & 0.040 & 0.054 & 0.046 \\
\hline & $\begin{array}{l}(0.018 / \\
0 \cdot 131)\end{array}$ & $\begin{array}{l}(0.022 / \\
0 \cdot 158)\end{array}$ & $\begin{array}{l}(0.003 / \\
0.025)\end{array}$ & $\begin{array}{l}(0.019 / \\
0 \cdot 133)\end{array}$ & $\begin{array}{l}(0.025 / \\
0 \cdot 180)\end{array}$ & $\begin{array}{l}(0.021 / \\
0 \cdot 153)\end{array}$ \\
\hline ICER & Rapid c-s & Rapid c-s & 14853 & Rapid c-s & Rapid c-s & Rapid c-s \\
\hline [EUR] & $\begin{array}{l}\text { (Rapid c- } \\
\text { s / Rapid } \\
\text { c-s) }\end{array}$ & $\begin{array}{l}\text { (Rapid c- } \\
\text { s / Rapid } \\
\text { c-s) }\end{array}$ & $\begin{array}{l}\text { (78 } 490 \text { / } \\
\text { Rapid c- } \\
\text { s) }\end{array}$ & $\begin{array}{l}\text { (Rapid c- } \\
\text { s/Rapid } \\
\text { C-s) }\end{array}$ & $\begin{array}{l}\text { (Rapid c- } \\
\text { s / Rapid } \\
\text { c-s) }\end{array}$ & $\begin{array}{l}\text { (Rapid c- } \\
\text { s / Rapid } \\
\text { c-s) }\end{array}$ \\
\hline
\end{tabular}

Rapid c-s = Rapid cost-savings

Scenarios description: (1. Data for HIV transmission per act / 2. Population (HIV viral load) / 3. Distribution for curve of time from diagnosis to start cART / 4. Adjusting risk transmission for HIV viral 
load

Scenario A1: 1. Baggaley 2018 / 2. All patients / 3.Generalized gamma distribution / 4. No adjusted

Scenario A2: 1. Baggaley 2018 / 2. All patients / 3.Generalized gamma distribution / 4. Adjusted

Scenario A3: 1. Baggaley 2018 / 2. Patients with 1.70 - 3.54 log10 copies/ml / 3.Generalized gamma distribution / Adjusted

Scenario S1: 1. Patel 2014 / 2. All patients / 3.Weibull distribution / 4. No adjusted

Scenario S2: 1. Lasry 2014 / 2. All patients / 3.Weibull distribution / 4. No adjusted

Scenario S3: 1. Baggaley 2018 / 2. All patients / 3.Weibull distribution / 4. Adjusted

\section{Figures}

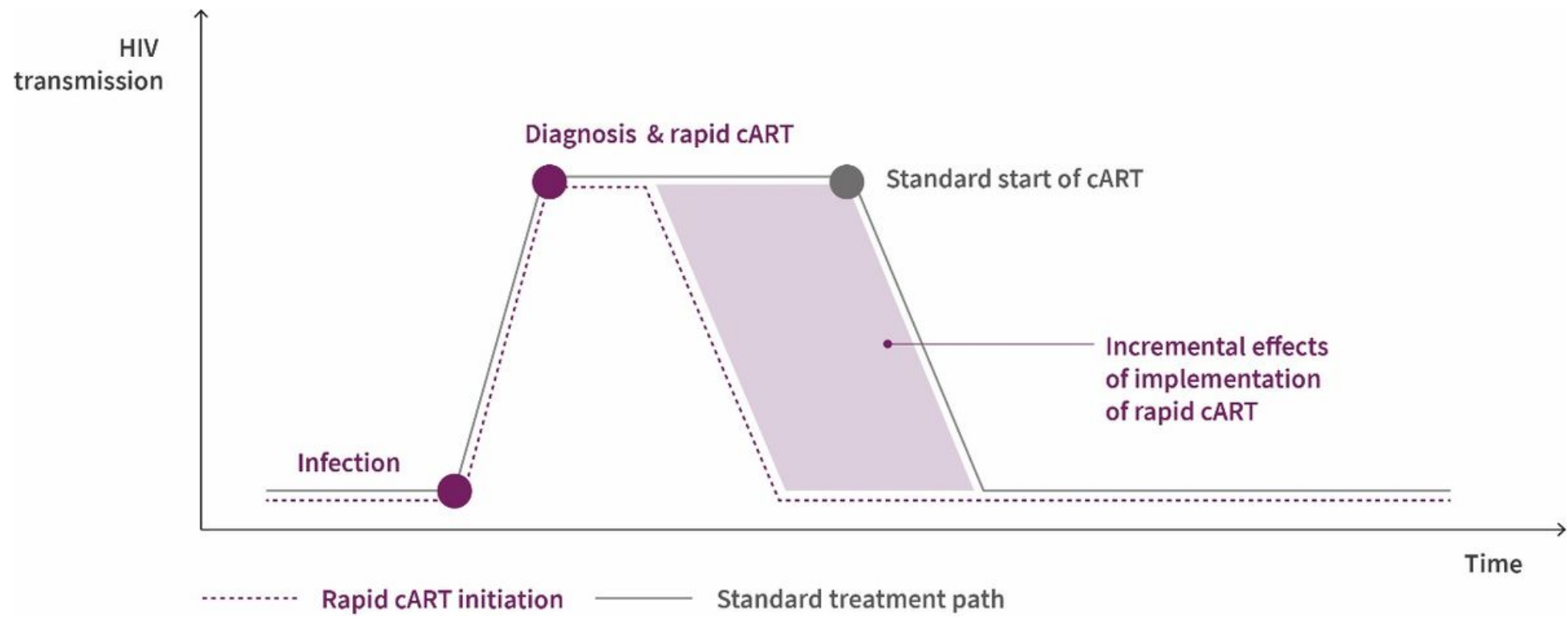

\section{Figure 1}

Simplified comparison of pathways treatment 


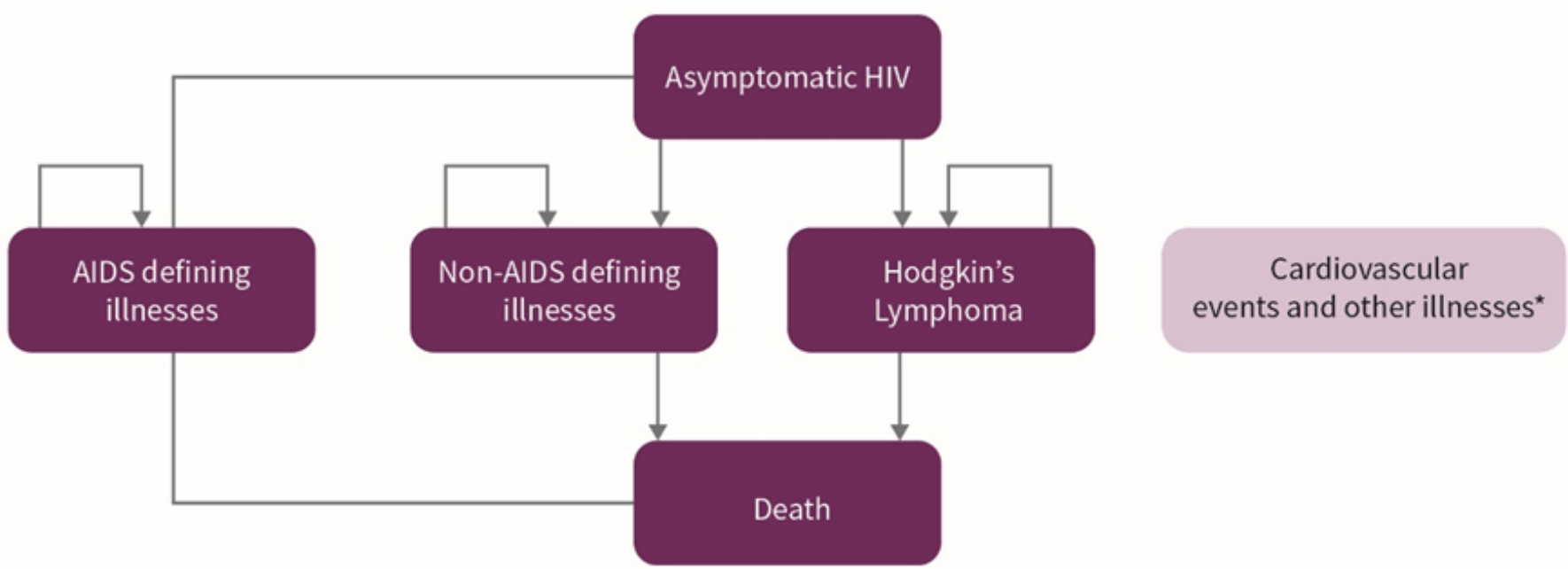

Figure 2

Markov model for HIV treatment *They do not determine independent health states. Only additionally costs and deaths due to cardiovascular events and other illnesses were charged, regardless of the state of health in each cycle of analysis.

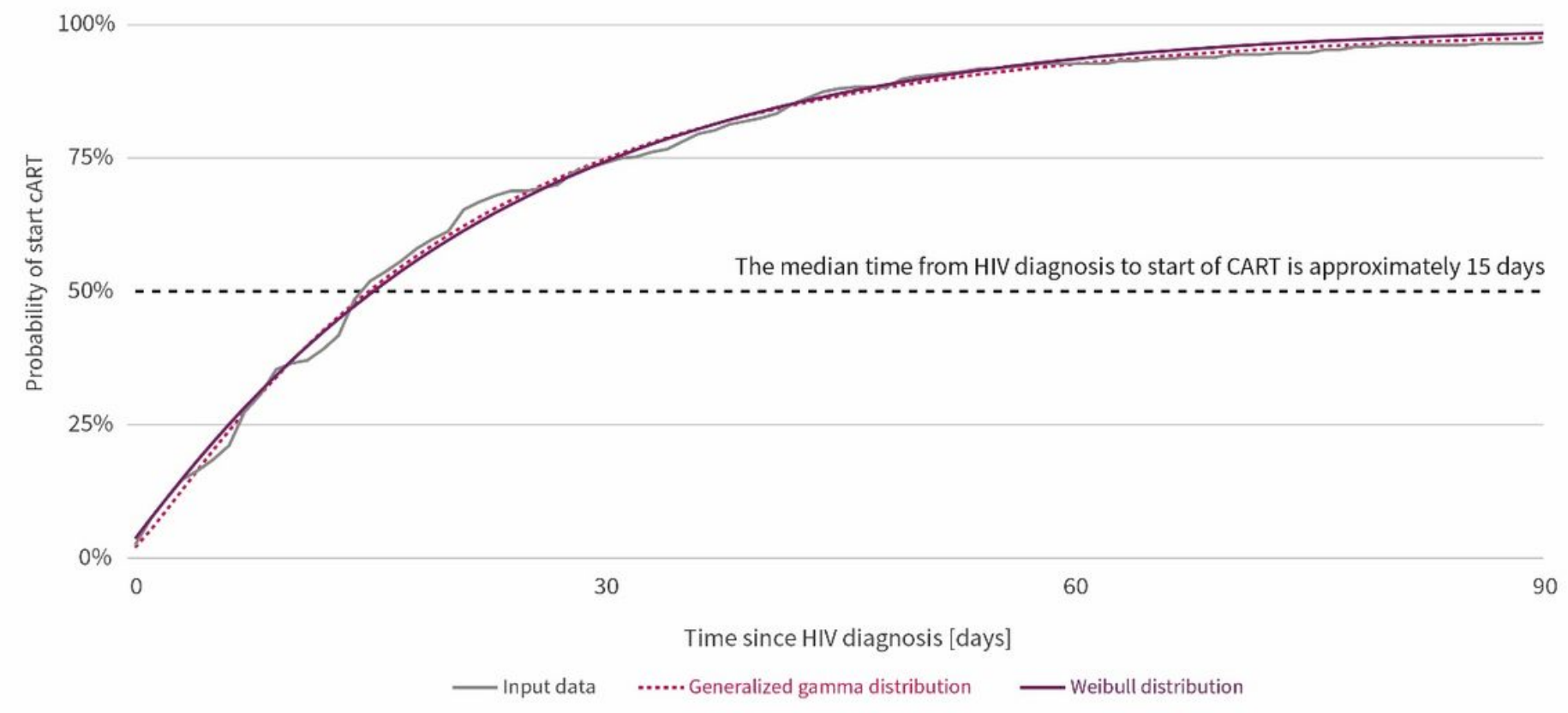

Figure 3

Time from diagnosis to start cART treatment 